\title{
GAME ARTIFICIAL INTELEGENT: RAM CITY TOWER DENGAN ALGORITMA A*
}

\author{
Gina Rahayu Meliani ${ }^{1}$ \\ Andri Suryadi ${ }^{2}$ \\ Sekolah Tinggi Keguruan dan Ilmu Pendidikan Garut \\ Program Studi Pend. Teknologi Informasi \\ 1 ginameilan1996@gmail.com \\ 2 suryadi.andri@yahoo.com
}

\begin{abstract}
Game merupakan salah satu hasil kemajuan teknologi yang paling banyak digunakan di semua kalangan. Game dirancang sedemikian rupa sehingga menarik perhatian banyak orang. Mulai dari game yang mudah sampai yang sulit untuk dimainkan. Game memiliki banyak jenis yang disesuaikan dengan kebutuhan penggunannya. Masing-masing game memiliki daya tarik yang berbeda, tergantung kebutuhan pengguna. Dalam merancang sebuah game tentu memiliki kesulitan tersendiri. Game disesuaikan dengan pola pikir pembuatnya. Sebuah cara untuk merepresentasikan pola pikir manusia dalam sebuah game dapat diartikan sebagai kecerdasan buatan. Dalam beberapa game dapat ditemukan sebuah kecerdasan buatan yang diimplementasikan seperti contohnya game Tic Tac Toe. Sebuah game yang dirancang dengan kecerdasan buatan lebih memicu cara berfikir pemainnya karena kecerdasan buatan ini sengaja dibuat untuk memicu cara berfikir pemain melawan komputer. Dengan adanya asumsi seperti yang disebutkan sebelumnya bahwa game yang mengimplementasikan kecerdasan buatan dapat dijadikan sebagai media pembelajaran sehingga belajar pun dapat lebih menyenangkan jika disajikan dengan sebuah game. Kecerdasan buatan memiliki beberapa jenis algoritma yang dapat digunakan, salah satu contohnya adalah algoritma $A^{*}$. Dengan demikian game kecerdasan buatan dapat dijadikan sebuah media pembelajaran yang disesuaikan dengan algoritma yang akan kita gunakan. Salah contohnya adalah game RAM City Tower. Game ini merupakan game kecerdasan buatan dengan jenis game platform yang memakai algoritma $A^{*}$. Game ini dibuat untuk membantu pengguna mengenal antonim dalam Bahasa Indonesia.
\end{abstract}

Kata kunci: Game, A*, Kecerdasan Buatan, Tower, Antonim, Bahasa Indonesia

\section{PENDAHULUAN}

Perkembangan game dalam dunia industri saat ini sudah sangat berkembang dengan pesat. Mulai dari game sederhana sampai game rumit. Dan bahkan alat pendukung seperti PlayStation dan Android sudah menciptakan beberapa generasi dan versi sebagai alat pendukung dalam mengimplementasikan sebuah game. Saat ini berbagai macam jenis game sudah mulai disebar luaskan, atau istilahnya disebut dengan genre game.

Game merupakan sebuah program/aplikasi yang berinteraksi dengan manusia. Perbedaannya adalah game lebih mengandung unsur kesenangan kepada pemainnya. Dampak dari game tidak langsung dapat dirasakan. Namun, dampaknya bisa saja berupa kepuasan pemain. Game terdiri dari game 2 dimensi dan 3 dimensi bahkan sekarang sedang berkembang game 4 dimensi yang tampilannya sudah divisualkan layaknya objek nyata. Sampai saat ini banyak sekali aplikasi-aplikasi yang menyediakan layanan untuk membuat game seperti contoh adobe flash, blender, unity, game maker RPG dan lainlain.

Dengan beragamnya bentuk game, kini kita juga dapat menikmati game yang amat cerdas, yang mana dengan mengikuti permainan pada game ini kita dapat merasakan bahwa game ini bukan hanya interaksi satu arah saja, namun berinteraksi dua arah. Kita dapat merasakan bahwa kita sedang bermain dengan sesama manusia bukan dengan mesin karena dengan adanya interaksi yang diberikan oleh sistem sama halnya dengan berintaksi dengan manusia. Salah satu contohnya yaitu game yang dibuat untuk mengendalikan sesuatu, untuk perencanaan dan penjadwalan, kemampuan untuk menjawab diagnosa dan pertanyaan pelanggan, serta pengenalan tulisan tangan, suara dan wajah. 
Game seperti ini kini telah marak digunakan dan sangat banyak diminati oleh berbagai kalangan diberbagai bidang kehidupan, tidak terkecuali kalangan di bidang pendidikan dengan tujuan untuk memberikan pembelajaran. Salah satunya adalah dengan diciptakannya sebuah game yang dijadikan media pembelajaran. Pada prinsipnya konteks sebuah media pembelajaran adalah menjadi penghubung dalam proses belajar mengajar dengan adanya komunikasi antara pemberi informasi dengan penerima informasi. Konsep komunikasi dengan media dalam dunia pendidikan tidak jauh berbeda dengan komunikasi pada umumnya kecuali pada sisi kontek berlangsungnya informasi.

\section{LANDASAN TEORI}

\subsection{Game dalam Pendidikan}

Dalam dunia pendidikan hal yang perlu diperhatikan dalam penyampaian materi adalah interaksi antara penyampai dan penerima. Tentunya dalam hal ini adanya komunikasi antara kedua pihak dapat membantu jalannya proses belajar mengajar. Dalam proses pembelajaran, yang menjadi sumber informasi adalah guru, siswa, bahan bacaan dan lain sebagainya. Sedangkan penerima informasi mungkin juga guru, siswa, serta orang lain. Sebuah teknologi yang dapat dijadikan sebagai teknologi pembawa pesan yang dapat digunakan sebagai sarana pembelajaran atau secara fisik untuk menyampaikan pembelajaran disebut sebagai media. Selain itu hal yang perlu diperhatikan dalam proses pembelajaran adalah metode pembelajaran yang dirancang untuk membantu siswa bejalar lebih baik lagi. Sehingga dapat kita lihat arah komunikasi dala dunia pendidikan adalah seperti berikut:

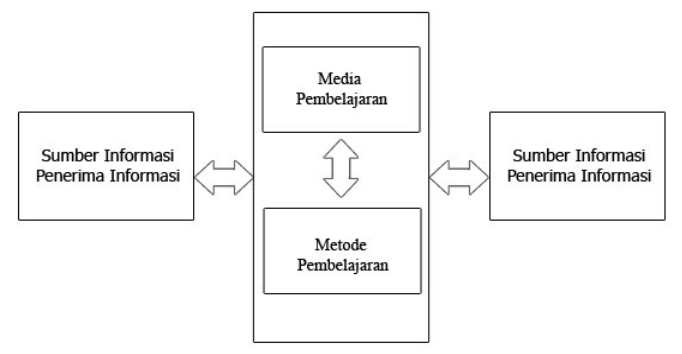

\section{Gambar 2.1}

Metode pembelajaran dapat berupa tanya jawab, simulasi, seminar, ceramah dan lain sebagainya. Dalam sebuah game metode pembelajaran yang dipakai biasanya berupa tanya jawab dan simulasi.dilihat dari kata Game berasal dari bahasa Inggris. Dalam kamus bahasa Indonesia istilah "Game" adalah permainan. Permainan dalam hal ini merujuk pada pengertian kelincahan intelektual ( Intellectual Playability Game) yang juga bisa diartikan sebagai arena keputusan dan aksi pemainnya biasanya dalam konteks tidak serius atau dengan tujuan refreshing. Biasanya game dalam media pembelajaran dilengkapi dengan Al (Artificial Intelegent) atau disebut juga dengan kecerdasan buatan dengan menggunakan tingkat kesulitan yang berbedabeda.

\subsection{Artificial Intelegent}

AI dapat didefinisikan sebagai suatu mesin atau alat pintar (biasanya adalah suatu komputer) yang dapat melakukan suatu tugas yang bila tugas tersebut dilakukan oleh manusia akan dibutuhkan suatu kepintaran untuk melakukannya. Definisi ini tampaknya kurang begitu membantu, karena beberapa ahli berpendapat :

- H.A Simon (1987):

"kecerdasan buatan merupakan kawasan penelitian, aplikasi dan instruksi yang terkait dengan pemrograman komputer untuk melakukan sesuatu hal yang dalam pandangan manusia adalah cerdas".

- $\quad$ Rich and Knight (1991):

"sebuah studi tentang bagaimana membuat komputer melakukan hal-hal yang pada saat ini dapat dilakukan dengan lebih baik oleh manusia".

- Encyclopedia Britannica:

"merupakan cabang dari ilmu computer yang dalam merepresentasi pengetahuan lebih banyak menggunakan bentuk symbol-simbol dari bilangan, dan memproses informasi berdasarkan metode heuristic atau berdasarkan sejumlah aturan".

- John McCarthy [1956]

Kecerdasan buatan (Artificial Intelligence) ialah Memodelkan proses berpikir manusia dan mendesain mesin agar menirukan perilaku manusia.

Dari beberapa pengertian diatas, dapat disimpulkan bahwa pengertian dari kecerdasan buatan adalah suatu inovasi yang dilakukan menggunakan perangkat komputer sehingga menghasilkan sesuatu yang baru dan membuat komputer mampu berinteraksi sama dengan manusia.

Kecerdasan buatan berhubungan dengan 2 ide dasar. Yang pertama menyangkut pada proses berfikir manusia, dan yang kedua berhubungan denganmempresentasikan proses tersebut melalui sebuah teknologi.

\subsection{Algoritma A* (Path Finding)}

Pathfinding merupakan cara untuk mendapatkan route antara 2 buah point. Pathfinding memiliki beberapa algoritma yang bisa diterapkan antara lain.

A. Brute Force

Algoritma ini merupakan algoritma yang paling mudah dimengerti. Cara kerjanya adalah membandingkan posisi sekarang dengan posisi tujuan dan menentukan langkah berikutnya.

B. BFS 
Breadth-First Search merupakan algortima yang menyelesaikan masalah dengan memanfaatkan struktur pohon.

C. DFS

Deep-First Search merupakan algoritma yang menyeleseaikan masalah dengan memanfaatkan struktur pohon. DFS mencari solusi ke node yang paling dalam pada pohon.

D. Branch and Bound dan A*

Branch and Bound merupakan pengembangan dari BFS. Pada Branch and Bound, setiap node memiliki harga (dengan cara penghitungan harga yang bermacam-macam). Harga node menentukan kedekatan node dengan solusi. Algoritma A* (Baca : A bintang) merupakan salah satu pengembangan dari Algoritma Branch and Bound. Perhitungan harga pada algoritma $\mathrm{A}^{*}$ memanfaatkan unsur heuristik pada benda.

Namun pada game ini dipakai Algoritma A* karena Algoritma ini banyak dipakai dalam pembuatan game AI.

\section{IMPLEMENTASI}

\subsection{Data Penelitian}

Untuk mendukung kelayakan game ini maka diperlukan data dari uji kelayakan game/aplikasi. Uji coba yang dilakukan adalah dengan menggunakan uji kelayakan Ahli Media dan Ahli Materi.

\subsubsection{Uji Media}

Ahli media dan ahli materi. Digunakan untuk mengetahui kelayakan media dalam validasi ahli media. Pada penelitian ini uji media dilakukan oleh beberapa ahli dengan beberapa indicator diantanranya:

Tabel 3.1. Uji Media

\begin{tabular}{|l|l|lllll|}
\hline No & Soal & \multicolumn{4}{|l|}{ Indikator } \\
\hline 1 & $\begin{array}{l}\text { Aplikasi Berjalan } \\
\text { Lancar }\end{array}$ & 1 & 2 & 3 & 4 & 5 \\
\hline 2 & $\begin{array}{l}\text { Keefektifan pengguna } \\
\text { resource (RAM, CPU, } \\
\text { dan Harddisk) }\end{array}$ & 1 & 2 & 3 & 4 & 5 \\
\hline
\end{tabular}

\begin{tabular}{|c|c|c|c|c|c|c|}
\hline 3 & $\begin{array}{l}\text { Aplikasi tidak hilang } \\
\text { saat digunakan }\end{array}$ & 1 & 2 & 3 & 4 & 5 \\
\hline 4 & $\begin{array}{l}\text { Aplikasi tidak } \\
\text { mengganggu kinerja } \\
\text { aplikasi lain }\end{array}$ & 1 & 2 & 3 & 4 & 5 \\
\hline 5 & $\begin{array}{l}\text { Aplikasi bisa berjalan } \\
\text { tanpa adanya aplikasi } \\
\text { tertentu }\end{array}$ & 1 & 2 & 3 & 4 & 5 \\
\hline 6 & $\begin{array}{l}\text { Kemudahan } \\
\text { pengelolaan program }\end{array}$ & 1 & 2 & 3 & 4 & 5 \\
\hline 7 & $\begin{array}{l}\text { Kemudahan dalam } \\
\text { pengoprasian }\end{array}$ & 1 & 2 & 3 & 4 & 5 \\
\hline 8 & $\begin{array}{l}\text { Sederhana dalam } \\
\text { pengoprasian }\end{array}$ & 1 & 2 & 3 & 4 & 5 \\
\hline 9 & $\begin{array}{l}\text { Aplikasi dapat dikelola } \\
\text { dengan mudah }\end{array}$ & 1 & 2 & 3 & 4 & 5 \\
\hline 10 & $\begin{array}{l}\text { Menggunakan } \\
\text { algoritma yang tidak } \\
\text { rumit }\end{array}$ & 1 & 2 & 3 & 4 & 5 \\
\hline 11 & $\begin{array}{l}\text { Aplikasi dapat } \\
\text { dijalankan di berbagai } \\
\text { device lain }\end{array}$ & 1 & 2 & 3 & 4 & 5 \\
\hline 12 & $\begin{array}{l}\text { Konten dlam aplikasi } \\
\text { dapat dimanfaatkan } \\
\text { kembali }\end{array}$ & 1 & 2 & 3 & 4 & 5 \\
\hline 13 & $\begin{array}{l}\text { Sound effect yang } \\
\text { digunakan menarik }\end{array}$ & 1 & 2 & 3 & 4 & 5 \\
\hline 14 & $\begin{array}{l}\text { Sound effect yang } \\
\text { digunakan tidak } \\
\text { mengganggu }\end{array}$ & 1 & 2 & 3 & 4 & 5 \\
\hline 15 & $\begin{array}{l}\text { Sound effect yang } \\
\text { digunakan menarik }\end{array}$ & 1 & 2 & 3 & 4 & 5 \\
\hline
\end{tabular}




\begin{tabular}{|c|c|c|c|c|c|c|}
\hline 16 & $\begin{array}{l}\text { Pemilihan warna yang } \\
\text { tepat }\end{array}$ & 1 & 2 & 3 & 4 & 5 \\
\hline 17 & $\begin{array}{l}\text { Tulisan dapat terbaca } \\
\text { dengan baik }\end{array}$ & 1 & 2 & 3 & 4 & 5 \\
\hline 18 & Tampilan menarik & 1 & 2 & 3 & 4 & 5 \\
\hline 19 & Navigasi sederhana & 1 & 2 & 3 & 4 & 5 \\
\hline 20 & $\begin{array}{l}\text { Navigasi berfungsi } \\
\text { dengan baik }\end{array}$ & 1 & 2 & 3 & 4 & 5 \\
\hline 21 & $\begin{array}{l}\text { User berinteraksi } \\
\text { dengan aplikasi }\end{array}$ & 1 & 2 & 3 & 4 & 5 \\
\hline 22 & $\begin{array}{l}\text { Penggunaan bahasa } \\
\text { yang komunikatif }\end{array}$ & 1 & 2 & 3 & 4 & 5 \\
\hline 23 & $\begin{array}{l}\text { Kreatif dalam } \\
\text { menuangkan ide } \\
\text { gagasan }\end{array}$ & 1 & 2 & 3 & 4 & 5 \\
\hline 24 & $\begin{array}{l}\text { Animasi yang } \\
\text { digunakan menarik }\end{array}$ & 1 & 2 & 3 & 4 & 5 \\
\hline 25 & $\begin{array}{l}\text { Animasi yang } \\
\text { digunakan tidak } \\
\text { mengganggu }\end{array}$ & 1 & 2 & 3 & 4 & 5 \\
\hline 26 & Kejelasan gambar & 1 & 2 & 3 & 4 & 5 \\
\hline
\end{tabular}

Teknik analisis data untuk kelayakan ahli media menggunakan analisis deskriptif. Data yang diperoleh dari hasil validasi ahli media adalah data angket yang dikonversikan menjadi skor dengan skala Likert level 5 .

Kemudian data dianalisis dengan menghitung rata-rata jawaban berdasarkan skoring setiap jawaban dari responden

Nilai rerata jawaban dapat dihitung berdasarkan jumlah skor jawaban seluruh responden dibagi jumlah responden kali jumlah butir instrumen .
Setelah itu, menyusun tabel klasifikasi dengan menggunakan rata-rata skor. Adapun yang perlu dicari adalah skor tertinggi, skor terendah, jumlah kelas, dan jarak interval.

Perhitungan Klasifikasi Ahli

Skor tertinggi $=5$ (sangat setuju)

Skor terendah $=1$ (sangat tidak setuju)

Jumlah kelas $=5$ (sangat tidak setuju sampai sangat setuju)

Jumlah Interval $=\frac{\text { Skor tertinggi-skor terendah }}{\text { Jumlah Kelas Interval }}$

Tabel 3.2. Klasifikasi uji kelayakan

\begin{tabular}{|l|l|}
\hline Rerata Jawaban & Klasifikasi \\
\hline a - b & Sangat layak \\
\hline b - c & Layak \\
\hline c - d & Cukup Layak \\
\hline d - e & Tidak Layak \\
\hline e - f & Sangat tidak layak \\
\hline
\end{tabular}

\subsubsection{Uji Materi}

Pada pengujian materi ini menggunakan Skala Guttman yang berasal dari penggumpulan data melalui angket.

\subsection{Perancangan perangkat lunak model Waterfall}

Desain penelitian menggunakan model sekuensial linear atau sering disebut dengan model air terjun (waterfall). Desain penelitian dapat dilihat pada gambar berikut: 


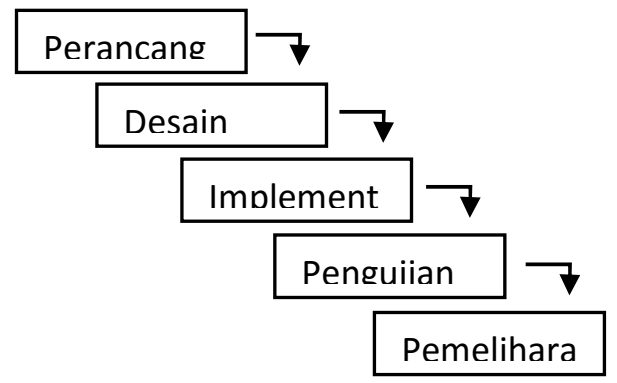

\section{Gambar 3.1 Model Waterfall}

Desain penelitian meliputi aktivitas-aktivitas berikut: Pemodelan sistem informasi harus dilakukan terlebih dahulu sebelum mulai melakukan implementasi program atau pengkodean program. Pemodelan sistem informasi ini bertujuan untuk menemukan batasan-batasan masalah pada penerapan sistem.

\subsubsection{Analisis}

Tahan ini merupakan tahap awal dalam pengembangan sebuah perangkat lunak, tahapan ini digunakan untuk mengetahui informasi, model, dan spesifikasi dari sistem yang dibutuhkan, baik kebutuhan fungsional maupun kebutuhan non fungsional.

Kebutuhan funsional merupakan kebutuhan utama yang berkaitan langsung dengan pelayanan sistem pengambilan keputusan yang meliputi dibagi menjadi beberapa modul seperti yang tercantum dalam tabel di bawah ini:

Tabel 3.3 Kebutuhan Fungsionl

\begin{tabular}{|l|l|}
\hline No & Deskripsi Kebutuhan Fungsional \\
\hline 1 & Menu untuk memudahkan pengguna \\
\hline 2 & $\begin{array}{l}\text { Pengelolaan menu dengan dilengkapi intruksi } \\
\text { penggunaan game }\end{array}$ \\
\hline 3 & $\begin{array}{l}\text { Penggunaan pop up menu untuk membantu } \\
\text { pengguna mencari informasi }\end{array}$ \\
\hline
\end{tabular}

\begin{tabular}{|l|l|}
\hline 4 & $\begin{array}{l}\text { Penggunaan menu restart dan quit pada saat } \\
\text { game selesai }\end{array}$ \\
\hline
\end{tabular}

Tabel 3.4 Kebutuhan non fungsional

\begin{tabular}{|l|l|}
\hline No & Deskripsi Kebutuhan Non-Fungsional \\
\hline 1 & $\begin{array}{l}\text { Kemudahan pemakaian pada berbagai jenis } \\
\text { window }\end{array}$ \\
\hline 2 & Tidak pernah gagal pada saat proses instalasi \\
\hline 3 & User Interface menggunakan bahasa Indonesia \\
\hline 4 & Waktu akses game relative cepat \\
\hline 5 & Tidak membebani computer pada saat dijalankan \\
\hline 6 & Mudah untuk menutup jendela game \\
\hline
\end{tabular}

\subsubsection{Desain Sistem}

Tahapan kedua dari model waterfall adalah desain dimana pada tahapan ini bertujuan membuat desain dari hasil analisis yang dilakukan pada tahapan pertama. Informasi, model dan spesifikasi yang diubah menjadi sebuah desain sistem yang nantinya akan dikodekan.

Algoritma yang telah dibuat kemudian digambarkan dalam bentuk bagan alir (flowchart) dengan menggunakan simbol-simbol untuk memudahkan memecahkan masalah yang akan diselesaikan. Flowchart adalah skema penggambaran dari algoritma yang disusun dalam bentuk bagan secara berurutan. Dibawah ini gambar dari flowchart untuk game: 
Tahap selanjutnya dari model Waterfall dalam

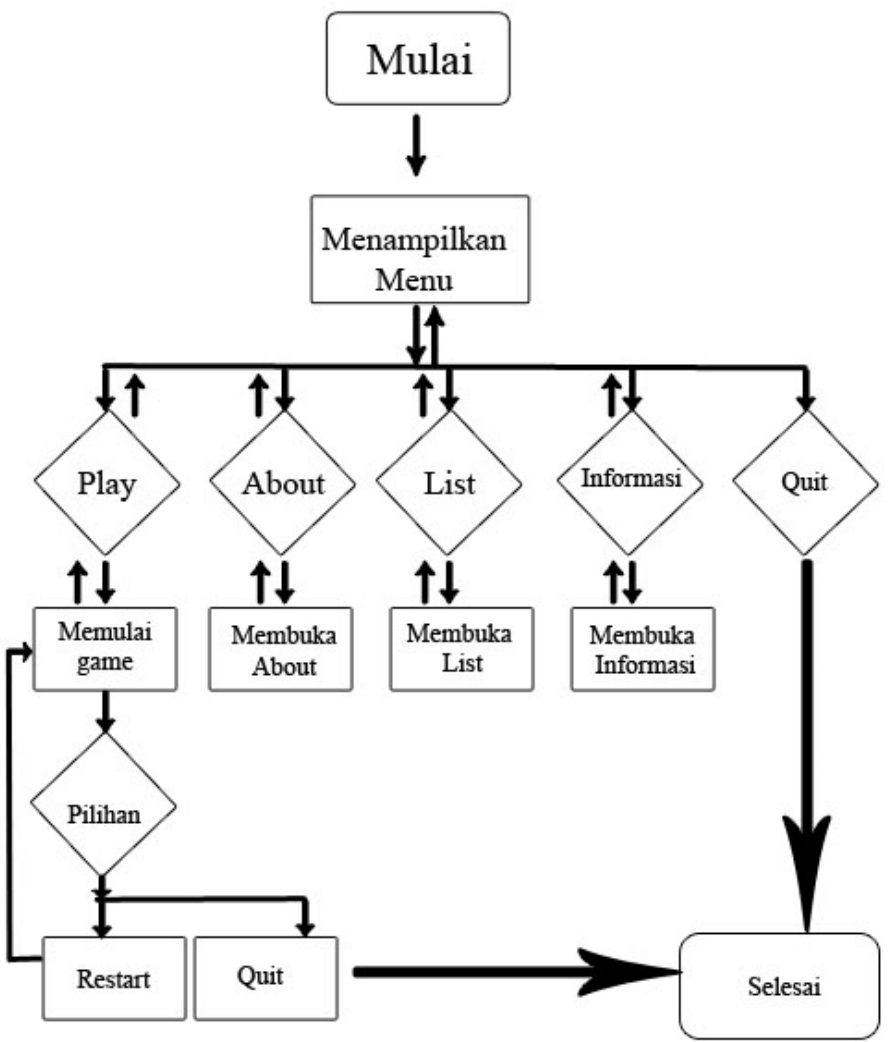

pengembangan sistem pengambilan keputusan adalah tahap impementasi. Tahapan ini ada tahap pengembangan dengan melakukan pengkodean. Hasil dari pengkodean menghasilkan perangkat lunak. Pada penelitian ini perangkat lunak pada pembuatan game iini antara lain:
1. Inkscape
2. Adobe Photoshop
3. Unity
4. MonoDevelop
5. Visual Studio
6.

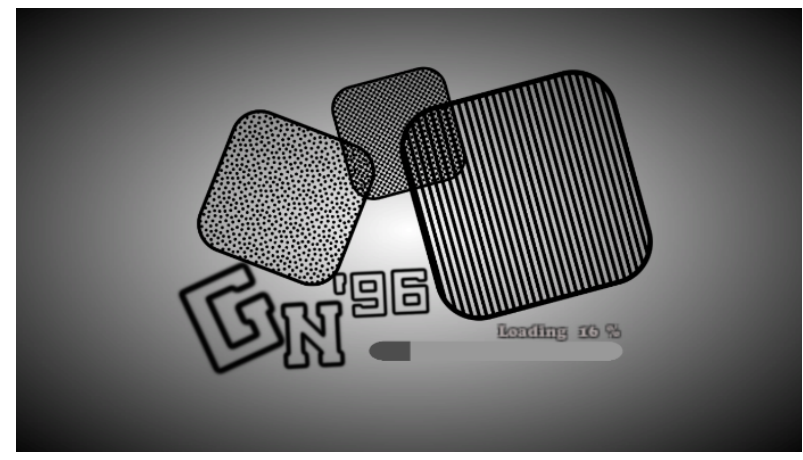

Gambar 3.3 Tampilan 1

Gambar 3.2

Gambar flowchart diatas merupakan gambaran dari alur data yang ada pada game. Dibawah ini merupakan penjelasan dari lebih lengkap dari alur datanya.

1) Memulai aplikasi

2) Menampilkan menu dengan sub menu diantaranya play, about, list, informasi dan quit.

3) Jika pemain memilih play maka permainan dimulai namun jika pemain kalah maka akan muncul pilihan untuk merestart game atau mengakhiri permainan

4) Quit untuk mengkhiri aplikasi

\subsubsection{Implementasi / Koding}

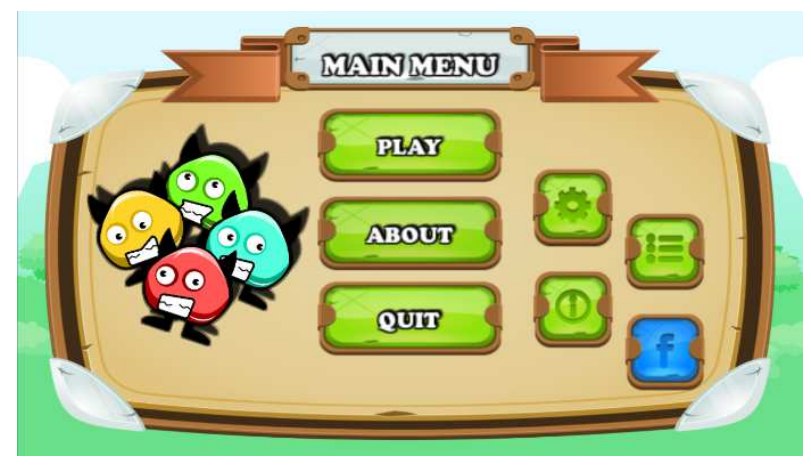

\section{Gambar 3.4 Tampilan 2}




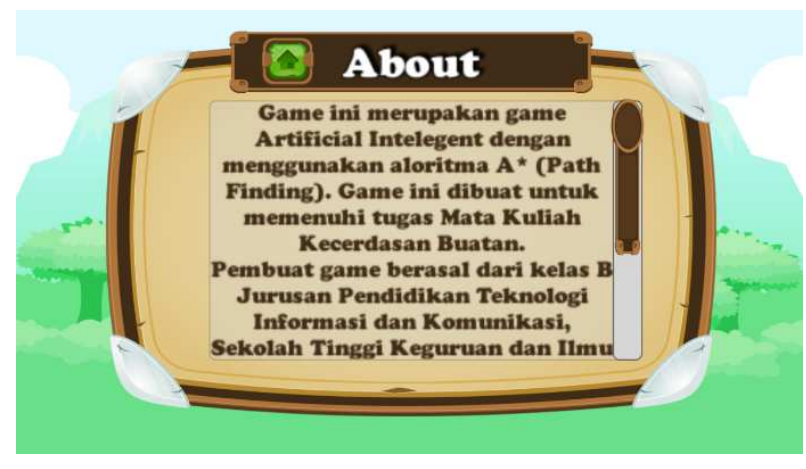

Gambar 3.5 Tampilan 3

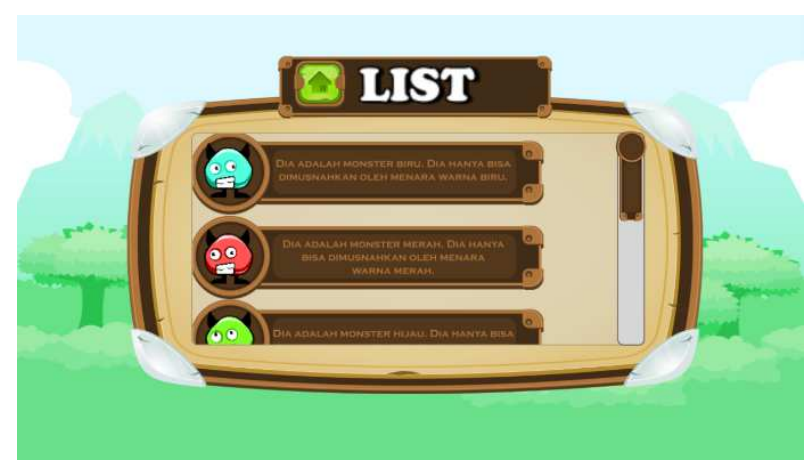

Gambar 3.6 Tampilan 4

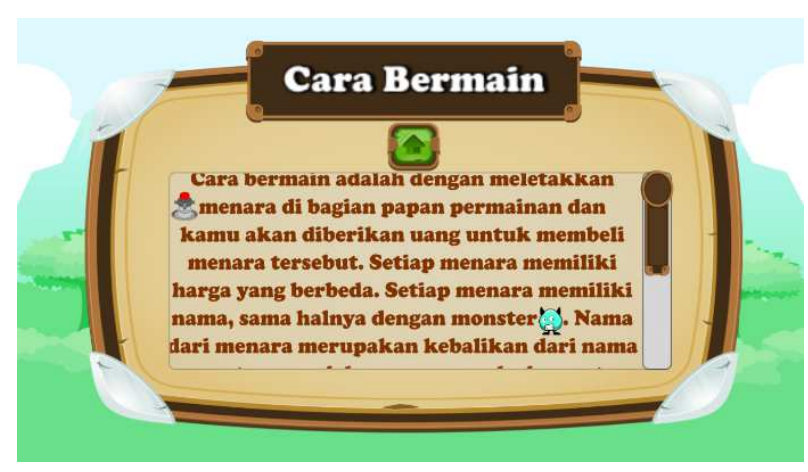

Gambar 3.7 Tampilan 5

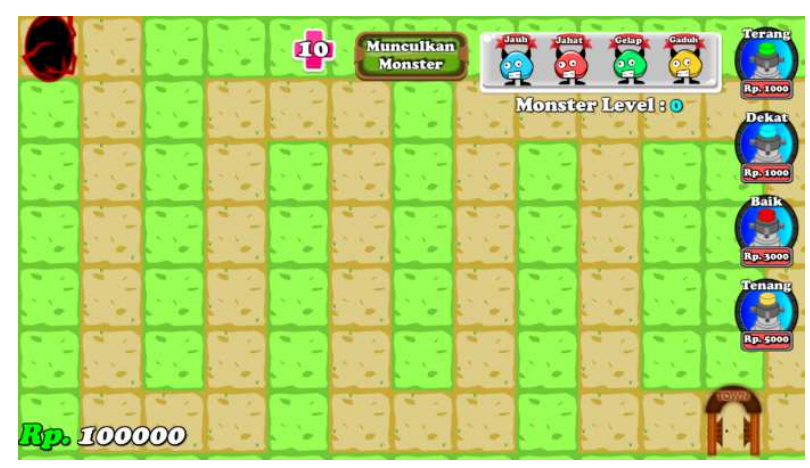

Gambar 3.8 Tampilan 6

\subsubsection{Pengujian}

Tahapan terakhir dalam model waterfall adalah tahapan pengujian, dimana pada tahapan ini software yang telah dibuat diuji apakah sudah sesuai dengan kubutuhan atau belum. Dalam pengujian software ini dilakukan dengan pengujian Blackbox. Dibawah ini adalah sekenario yang dilakukan dalam pengujian menggunakan Blackbox:

Tabel 3.5

\section{Compability}

\begin{tabular}{|l|}
\hline Instrumen \\
\hline 1. Menjalankan Instaler aplikasi \\
\hline $\begin{array}{l}\text { 2. Mengatur kesesuaian dengan } \\
\text { device }\end{array}$ \\
\hline 3. Proses instalasi pada device \\
\hline 4. Menjalankan aplikasi \\
\hline 5. Menggunakan aplikasi \\
\hline $\begin{array}{l}\text { 6. Mensetting aplikasi sesuai } \\
\text { kebutuhan }\end{array}$ \\
\hline $\begin{array}{l}\text { 7. Mem-pause aplikasi untuk } \\
\text { menjalankan aplikasi lainnya }\end{array}$ \\
\hline 8. Menutup aplikasi \\
\hline 9. Melakukan update aplikasi \\
\hline 10. Men-uninstal aplikasi \\
\hline
\end{tabular}


Tabel 3.6 Hasil Uji Kelayakan

\begin{tabular}{|c|c|c|c|c|}
\hline No & Jenis & Versi OS & & Skor \\
\hline \multirow[t]{2}{*}{1} & \multirow[t]{2}{*}{$\begin{array}{l}\text { Window } \\
\text { XP }\end{array}$} & \multirow[t]{2}{*}{ SP 3} & $\begin{array}{l}\text { Proses } \\
\text { instalasi }\end{array}$ & 5 \\
\hline & & & $\begin{array}{l}\text { Proses } \\
\text { berjalan } \\
\text { aplikasi }\end{array}$ & 5 \\
\hline \multirow[t]{2}{*}{2} & \multirow[t]{2}{*}{$\begin{array}{l}\text { Window } \\
7\end{array}$} & \multirow[t]{2}{*}{$\begin{array}{l}\text { Ultimate, } \\
\text { Basic }\end{array}$} & $\begin{array}{l}\text { Proses } \\
\text { instalasi }\end{array}$ & 5 \\
\hline & & & $\begin{array}{l}\text { Proses } \\
\text { berjalan } \\
\text { aplikasi }\end{array}$ & 5 \\
\hline \multirow[t]{2}{*}{3} & \multirow[t]{2}{*}{$\begin{array}{l}\text { Window } \\
2010\end{array}$} & & $\begin{array}{l}\text { Proses } \\
\text { instalasi }\end{array}$ & 5 \\
\hline & & & $\begin{array}{l}\text { Proses } \\
\text { berjalan } \\
\text { aplikasi }\end{array}$ & 5 \\
\hline \multirow[t]{2}{*}{4} & \multirow[t]{2}{*}{ Linux } & & $\begin{array}{l}\text { Proses } \\
\text { instalasi }\end{array}$ & 5 \\
\hline & & & $\begin{array}{l}\text { Proses } \\
\text { berjalan } \\
\text { aplikasi }\end{array}$ & 5 \\
\hline \multirow[t]{2}{*}{5} & \multirow[t]{2}{*}{ Mac } & & $\begin{array}{l}\text { Proses } \\
\text { instalasi }\end{array}$ & 5 \\
\hline & & & $\begin{array}{l}\text { Proses } \\
\text { berjalan } \\
\text { aplikasi }\end{array}$ & 5 \\
\hline
\end{tabular}

\section{KESIMPULAN DAN SARAN \\ 4.1 Kesimpulan}

Dari penelitian yang telah dilakukan terdapat beberapa kesimpulan sebagai berikut:

1. Game dapat dijadikan sebagai media pembelajaran yang menyenangkan

2. Game dengan algoritma $A^{*}$ lebih meningkatkan kemampuan berfikir pemainnya

3. Game ini dapat dijadikan sebagai sumber ilmu pengetahuan

\subsection{Saran}

Saran dari peneliti untuk pembaca adalah sebagai berikut:

Alangkah lebih baik jika penambahan sinonim dan antonim pada game ini lebih banyak dan lebih luas.

\section{DAFTAR PUSTAKA}

[1] Achmad Balza.2006.Diktat Kecerdasan Buatan.Universitas Gajah Mada Yogyakarta

[2] Virvou, M. (2005). Combining Software Games with Education : Evaluation of Its Educational Effectivinnes. Journal Educational Technology andSociety,8(2), 54 - 65.

[3] Suryadi.Andri(2016). SISTEM PENDUKUNG KEPUTUSAN SELEKSI UJIAN MASUK PERGURUAN TINGGI MENGGUNAKAN NBC (NAÏVE BAYES CLASSIFIER). KINETIK, 2016

[4] Suryadi, A.(2017). PERANCANGAN APLIKASI GAME EDUKASI MENGGUNAKAN MODEL WATERFALL. Jurnal PETIK Vol.3 No.12017 